\title{
URBANISMO SOB A ÓTICA DE GÊNERO: O ESPAÇO URBANO (NÃO) VIVENCIADO PELA MULHER NO JARDIM ESPLANADA EM TEODORO SAMPAIO -SP
}

\author{
Bruna Eduarda de Lima Santos, Victor Martins de Aguiar, Yeda Ruiz Maria \\ Universidade do Oeste Paulista - UNOESTE, Presidente Prudente, SP. E-mail: brunaels@hotmail.com
}

\section{RESUMO}

O espaço urbano é constituído por diversas manifestações culturais e sociais advindas das vivências produzidas pela população, de modo, que fica evidente a importância de projetar locais mais inclusivos e participativos. Entretanto, os modelos urbanos às quais as cidades estão sendo planejadas seguem parâmetros socialmente construídos a partir das necessidades inerentes ao gênero masculino. A insuficiência de políticas públicas das pequenas e médias cidades do interior, assim como acontece nas grandes cidades, acarretam em problemas sociais e urbanos, conforme verificado no bairro Jardim Esplanada em Teodoro Sampaio, município do interior do Estado de São Paulo. Deste modo, este trabalho tem como objetivo analisar os usos urbanos por mulheres no Jardim Esplanada com o intuito de compreender os fatores de vulnerabilidade e destacar a necessidade de aplicação de políticas públicas de desenvolvimento urbano para a instituição de espaços urbanos mais inclusivos e igualitários ao gênero. Considerando o processo analítico, este estudo foi desenvolvido a partir de um "mapeamento intuitivo" produzido por observações diretas no local e demarcação das apropriações urbanas e áreas de vulnerabilidade vivenciadas pelas mulheres, servindo de principal fomento ao trabalho. Para complemento, também foi realizada revisão bibliográfica e documental.

Palavras-chave: mulher, direito à cidade, planejamento urbano, Jardim Esplanada, Teodoro Sampaio-SP.

\section{URBANISM FROM A GENDER PERSPECTIVE: THE URBAN SPACE (NOT) EXPERIENCED BY WOMEN IN JARDIM ESPLANADA IN TEODORO SAMPAIO -SP}

\begin{abstract}
The urban space is constituted by several cultural and social manifestations arising from the experiences produced by the population, so that it is evident the importance of designing more inclusive and participatory places. However, the urban models to which the cities are being planned follow socially constructed parameters based on the inherent needs of the male gender. The insufficiency of public policies in small and medium-sized cities in the interior, as well as in big cities, causes social and urban problems, as verified in the Jardim Esplanada neighborhood in Teodoro Sampaio, a city in the interior of São Paulo State. Thus, this paper aims to analyze urban uses by women in Jardim Esplanada in order to understand the vulnerability factors and highlight the need for the application of urban development public policies for the institution of more inclusive and gender-equal urban spaces. Considering the analytical process, this study was developed from an "intuitive mapping" produced by direct observations at the site and demarcation of urban appropriations and areas of vulnerability experienced by women, serving as the main stimulus for the work. To complement this, a bibliographic and documental review was also carried out.
\end{abstract}

Keywords: woman, right to the city, urban planning, Jardim Esplanada, Teodoro Sampaio - SP. 


\section{INTRODUÇÃO}

O termo gênero, apesar de não existir uma história linear sobre o seu surgimento, pode ser entendido como advindo de uma construção cultural de partes atribuídas aos sexos que limita espaços e estabelece as relações envolvendo o público e o privado. Partes estas, vistas em conjunto, mesmo que tenham formas de convivência opostas, referentes a formação das relações urbanas e domésticas a partir da hierarquia patriarcal existente (MONTANER; MUXI; 2014).

Por definição, as formas de utilização do espaço público, através das práticas de vivência e a relação direta que o ambiente possui com a diversidade de pessoas existentes, trazem consigo fatores ligados constantemente nas noções e práticas cidadãs da população dentro da cidade (GALLETI, 2017). Somando-se a isso, Lefebvre (2011), dispõe que o direito à cidade equivale ao direito à vida urbana, com ideias de caráter político, produtivos e emancipatórios de maneira a propor a produção de um espaço urbano onde as pessoas possam ser capazes de tomar o controle da vida cotidiana.

Ao que tange às condições ao direito à cidade, questionando os princípios liberais de cidadania, é fundamental considerar identidades sociais diferentes no contexto urbano. Um aglomerado de pessoas, que inclui identidades sociais, como: gênero, raça, classe social, etnia, religião, orientação sexual, entre outros aspectos. Estas, se relacionam e podem contribuir para uma vivência desigual onde, consequentemente, resulta em discriminação e violência (GALLETI, 2017). É um aspecto relacionado ao sistema de poder e opressão que as afetam, principalmente, em uma desigualdade de gênero, tendo em vista que as mulheres se encontram mais vulneráveis a violências no espaço público.

Inserindo o Brasil em tal contexto, o país se desenvolveu a partir de um sistema colonial, escravista e patriarcal, assim toda sua economia era voltada para abastecer Portugal. Desta maneira, as cidades brasileiras foram moldadas e baseadas em um padrão onde o homem branco era o detentor dos poderes, produzindo uma sociedade pautada na segregação da população indígena, negra e pobre, sendo que o gênero feminino também estava inserido nessas camadas sociais no âmbito de "servir". Todavia, as mulheres do país não deixaram de lutar pelo seu espaço e diretos nos anos seguintes, até mesmo no âmbito das políticas urbanas (SANTORO, 2008).

Com a incorporação de leis urbanas no Brasil e, já no século XXI, em concordância com a Constituição Federal de 1988, o Estatuto da Cidade $^{1}$ e a Resolução 25 do Conselho Nacional das Cidades ${ }^{2}$, a elaboração de um Plano Diretor é um serviço coletivo, portanto, deve contar com a participação popular em todas as etapas, pensando na cidade como um todo. No entanto, nos modelos de planejamento e desenvolvimento das cidades não tem se constatado reflexões a respeito da apropriação das mulheres no espaço urbano, visto que, ideologias modeladoras de comportamento ainda incidem sobre estas por meio de leis e normas, repercutindo na utilização do espaço construído (GONZAGA, 2004).

O planejamento urbano voltado para a perspectiva de gênero deve empenhar-se em pontuar os aspectos sociais e políticos, dentro dos territórios públicos e domésticos, onde trabalha pelo reconhecimento da diversidade cultural, não se limitando a propostas totalitárias e, sim, em estar atento às diferenças (SANTORO, 2008).

A influência doméstica na vida das mulheres incide diretamente em sua vida pública. Dessa maneira, uma forma para que a vida urbana e sua relação de identidade com o espaço público não seja prejudicada, é a reivindicação de equipamentos e serviços, de modo que, assim possam trabalhar, participar e ter sua vida doméstica resolvida, através de serviços públicos ou através das relações de comunidade (SANTORO, 2008).

O tempo diário das mulheres é definido com base nas necessidades da família, dentro de casa para dar assistência e suporte, principalmente, quando envolve a presença dos filhos. Este comportamento também reflete na mobilidade urbana, sendo que as mulheres se deslocam bem mais que os homens, devido a uma rotina atrelada aos afazeres familiares, por

\footnotetext{
${ }^{1}$ BRASIL. Lei 10.257 de 10 de julho de 2001. Dispõe sobre o Estatuto da Cidade. Brasília, 2001. Disponível em: http://www.planalto.gov.br/ccivil_03/LEIS/LEIS_2001/L10257.htm. Acesso em: 18 jul. 2021.

${ }^{2}$ BRASIL. Diário Oficial da União. Resolução 25 de 18 de março de 2005. Dispõe sobre a elaboração de Planos Diretores a todos os Municípios, de acordo com a Lei no 10.257/01 (Estatuto da Cidade). Brasília, 2005, p.102. Disponível em: https://www.jusbrasil.com.br/diarios/524527/pg-102-secao-1diario-oficial-da-uniao-dou-de-30-03-2005. Acesso em: 18 jul. 2021.
} 
outro lado, mantêm-se reprimidas no espaço privado (GALLEOTI, 1995).

A insegurança é algo constantemente enfrentado pelas mulheres dentro do perímetro urbano, muitas vezes, em razão do planejamento urbano insuficiente de determinadas áreas ociosas e com pouca circulação e iluminação, sobretudo nos períodos noturnos. Desta forma, a mobilidade das mulheres fica limitada, pelo fato, de se sentirem vulneráveis e suscetíveis a uma violência, já que o espaço urbano não oferece subsídios para protegê-las (GALLETI, 2017).

[...] as práticas cotidianas das mulheres são produto das relações de gênero, as discriminações e desigualdades nessas construções resultam da ordem patriarcal, que separa as esferas públicas e privadas, fazendo com que a vivência da mulher no espaço urbano seja diferenciada do homem, expressando-se nos sentimentos de medo e insegurança que fazem com que essas adotem táticas que acabam as excluindo desses espaços (GALLETI, 2017, p. 2).

A pesquisa \#meninapodetudo ${ }^{3}$ (2015), a partir de 2.285 mulheres entrevistadas, com idades entre 14 e 24 anos, constatou que $90 \%$ delas já deixaram de fazer alguma coisa por medo de sofrerem violência, como sair à noite, usar determinada roupa ou, até mesmo, de responder alguma cantada e assédio sofrido e, $77 \%$ delas relataram já ter sofrido algum tipo de violência. Essa pesquisa tinha como objetivo o recorte de gênero, com foco em como o machismo e a violência afetam as mulheres das classes $C, D$ e $E$, moradoras de 370 cidades brasileiras. Vale ressaltar, que durante esta pesquisa, a palavra "rua" foi a mais citada nas 2.285 respostas às perguntas: "A violência contra a mulher aparece em seu dia a dia? Como?". O espaço público foi visto, pela maior parte das entrevistadas, como um local em que não há segurança ou respeito

\footnotetext{
${ }^{3}$ Pesquisa nacional realizada pelo Énois Inteligência Jovem; Instituto Vladimir Herzog; Instituto Patrícia Galvão, 2015. Disponível em: https://dossies.agenciapatriciagalvao.org.br/fontes-e-pesquisas/wpcontent/uploads/sites/3/2018/08/ENOIS_meninapodetudo2015.pdf . Acesso em: 18 jul. 2021.
}

pelas mulheres, o que resulta em sentimento de constante medo.

O rápido crescimento das cidades teve como modelo a ocupação extensiva do território, marcada pela periferização das áreas menos favorecidas e pouco funcionais, no que diz respeito a sua morfologia. Tal pressão pela expansão horizontal da cidade é resultado, na maioria das vezes, da produção especulativa do espaço e nos valores que empreendimentos imobiliários podem proporcionar, como resultante, se tem territórios urbanos dispersos e com extensas áreas vazias criadas indiretamente, que interferem na dinâmica urbana (SANTORO; COBRA; BONDUKI, 2000).

A criação de novos parcelamentos urbanos, nem sempre equivalem a escassez de áreas para moradia, pois há diversos municípios onde existem lotes vazios e sem uso, e, mesmo assim, se criam novos loteamentos. Estes loteamentos aumentam ainda mais a demanda no campo da especulação imobiliária e o espraiamento da malha urbana, tal como se percebe no Jardim Esplanada em Teodoro Sampaio, objeto de estudo deste trabalho.

Na conceituação do termo "vazio urbano" são abertas possibilidades de relações com as diversas formas de uso ou de não uso dos espaços, de modo que pode ser atribuído significado com base no contexto e abordagem social (FREITAS; NEGRÃO, 2014). Contudo, considerando que a criação de lacunas na malha urbana é consequência de um processo econômico e social, pode-se compreender que um vazio urbano remete a ausência de apropriação da população residente da cidade.

A incoerência na distribuição das áreas urbanas é um fator muito presente e definidor de desigualdades, entretanto, nem todo vazio urbano é fruto de uma retenção imobiliária, os motivos da terra permanecer vazia podem variar, desde algum embate jurídico até a falta de demanda no mercado (MORAES, 2018).

Conforme descreve o art. 2 da lei 10.257 do Estatuto da Cidade (2001), o planejamento urbano dos municípios deve estabelecer parâmetros urbanos de uso e ocupação do solo, a fim de evitar desde o uso inadequado e, inclusive, a não utilização do lote urbano. Tais diretrizes são expostas com o propósito de evitar lacunas e problemas que possam interferir no exercício da cidadania das pessoas.

Mesmo com o estabelecimento de leis urbanas, a falta de manutenção na infraestrutura 
desses espaços, muitas vezes, corrobora com fatores de insegurança, sobretudo presente em áreas periféricas, relacionando-se à falta de iluminação e ociosidade, por exemplo. Deste modo, lugares abandonados trazem maior insegurança para mulheres, visto que questões associadas à segurança, no contexto em que vivemos, possuem maior ameaça para elas do que para os homens (SANTORO, 2008).

Visto isso, vale ressaltar a importância de as diretrizes do planejamento urbano possibilitar a apropriação das mulheres nos ambientes públicos, favorecendo a sua presença e contribuindo para a sua inclusão à cidade e ao debate público. Assim, cabe analisar essa maneira de proceder em que o desenho urbano pode abranger aspectos sociais e ações com a finalidade de suscitar discussões sobre o tema, e proporcionar meios de conhecimento sobre a cidade e suas apropriações, bem como das políticas públicas.

Criar espaços de debates democráticos é um dos meios de contribuição para a constituição de políticas públicas inclusivas, mas a sociedade tende a não reconhecer os seus conflitos sociais e age de maneira excludente. Logo, um planejamento urbano que esteja comprometido com a inclusão social, requer uma abordagem integrada a partir de uma administração eficiente (MARICATO, 2015).

\section{[...] é preciso entender que não há ser humano padrão e que a cidade precisa dar conta de atender as necessidades de todas as pessoas que nela habitam - em que se pese as desigualdades existentes entre elas e a devida compensação. Enxergar o Planejamento Urbano e a cidade à luz de novas perspectivas, que complementem as ferramentas, práticas e conhecimentos que já nos utilizamos, é um caminho para que possamos construir cidades que proporcionem esta outra vivência, menos desigual (PECCINI, 2019, p. 58).}

A capacitação dos gestores à frente do planejamento urbano das cidades, em especial nas de médio e pequeno porte, é de suma importância para que haja o domínio sobre todos os aspectos sociais que envolvem as políticas públicas, assim como uma distribuição mais homogênea dos investimentos públicos e, segundo Maricato (2015, p. 96):

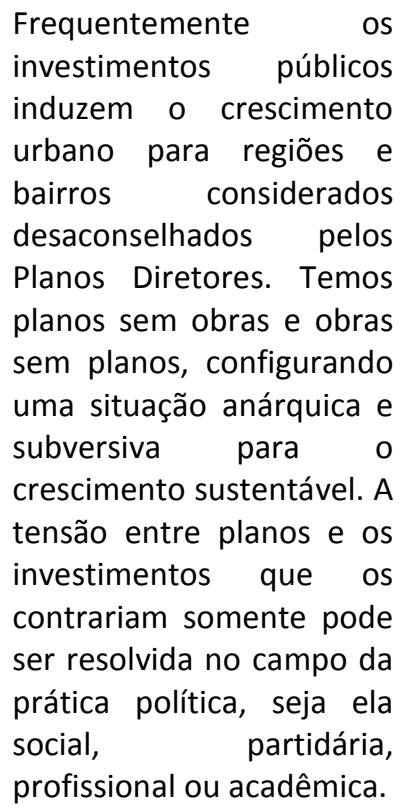

Deste modo, é neste contexto que este trabalho tem como objetivo compreender as dinâmicas de apropriação dos espaços urbanos e os pontos de vulnerabilidade vivenciados pelas mulheres no Jardim Esplanada em Teodoro Sampaio - SP, e como podem ser aplicadas políticas públicas que as contemplem, favorecendo o direito à cidade. Fundado entre as décadas de 1960 e 1970, em conjunto ao desenvolvimento da Estrada de Ferro Alta Sorocabana, o bairro hoje, 2021, configura-se dentro de uma morfologia periférica, em relação ao perímetro urbano do município. Ele possui condicionantes urbanas responsáveis por limitar as interações entre os cidadãos, causando insegurança para as mulheres, portanto, que acabam restringindo as relações de pertencimento e convívio coletivo, conforme será abordado.

\section{MÉTODOS}

Para alcançar o objetivo definido por este trabalho, conforme aprovado pelo Programa de Especial de Iniciação Científica da UNOESTE (PEIC), foi necessário analisar os registros históricos e os investimentos do poder público ao longo dos anos, com a finalidade de compreender a morfologia urbana no desenvolvimento do bairro Jardim Esplanada em Teodoro Sampaio $\mathrm{SP}$. Além disso, foram realizados levantamentos 
qualitativos in loco no bairro durante os meses de janeiro a março de 2020 e maio de 2021, em dias e horários diferentes. Por meio de observações diretas foi possível identificar, pontuar os locais de maior vulnerabilidade e insegurança vivenciados pelas mulheres e traçar comparativos entre os meses de análise, assim como as formas de apropriação.

Após a coleta de dados dos aspectos sociais e de infraestrutura do bairro, a partir da elaboração de croquis e "mapas mentais", foram realizados diagramas e mapas digitais com 0 auxílio do software Illustrator a fim de contribuir na compreensão dos levantamentos urbanos, gerando um "mapeamento intuitivo". Para ampliar as percepções espaciais do Jardim Esplanada, também foram realizados levantamentos fotográficos, destacando pontos específicos do bairro e houve a preservação da identidade dos moradores que transitavam no espaço, a partir da edição e desfoque de seus rostos.

As percepções físicas e dinâmicas sociais das mulheres moradoras do bairro, observadas nos levantamentos qualitativos, foram sintetizadas na forma de "mapas mentais", conforme propõe Kevin Lynch (1997), evidenciando as concepções de legibilidade do espaço urbano por parte de seus usuários. Estes "mapas mentais", foram complementados e embasados de acordo com a revisão bibliográfica, na conceituação de termos em livros, artigos, teses, dissertações e pesquisas científicas sobre: urbanismo feminista, planejamento urbano e direito à cidade.

Devido ao distanciamento social decretado em todo Estado de São Paulo, a partir de março de 2020, por conta do avanço da pandemia de COVID-19 no país, houve o fechamento das escolas e creches no município de Teodoro Sampaio, além de restrições ao uso das praças e demais espaços públicos ${ }^{4}$. Desta forma, os levantamentos e registros das apropriações urbanas das mulheres foram reduzidos dentro do período de distanciamento social decretado, porém a coleta de dados não foi prejudicada, pois foram mapeados e identificados

\footnotetext{
${ }^{4}$ TEODORO SAMPAIO. Decreto Municipal no. 2.566, de 7 de abril de 2020. Declara Estado de Calamidade Pública no Município de Teodoro Sampaio e dispõe sobre a adoção de novas medidas para intensificar o combate ao novo coronavírus (COVID-19). Disponível em:

https://www.teodorosampaio.sp.gov.br/temp/24072021205026ar quivo_DecretoMunicipal_.pdf. Acesso em: 24 jul. 2021.
}

os pontos de vulnerabilidade e as vivências urbanas antes das restrições sanitárias.

As novas observações realizadas no local de estudo em maio de 2021, assim como no ano anterior, foram pautadas a partir do decreto municipal ${ }^{5}$ e a respectiva fase de enfrentamento à pandemia disposta pelo Estado de São Paulo, onde o distanciamento social ainda se encontrava em vigor. No entanto, foi possível identificar as mudanças nos espaços e como estes elementos ainda continuam influenciando nas apropriações urbanas das mulheres no bairro Jardim Esplanada.

\section{RESULTADOS}

Os resultados obtidos estão fundamentados a partir do processo histórico de ocupação e desenvolvimento do bairro Jardim Esplanada e como atualmente, 2020-2021, ele é constituído dentro do perímetro urbano do município de Teodoro Sampaio - SP. À vista disso, é apresentado respectivamente, a localização do município e a sua formação urbana; o desenvolvimento do Jardim Esplanada e seu processo de ocupação, evidenciando o número de vazios urbanos ${ }^{6}$ existentes e os aspectos negativos desencadeados na malha urbana; a pontuação de aspectos de infraestrutura e acessibilidade no bairro, levantados com base nas visitas no local, e por fim, as políticas públicas existentes no município com relação ao planejamento urbano e a inserção da mulher na vivência coletiva.

\subsection{Reflexos urbanos: histórico, compreensão morfológica e políticas públicas}

As cidades do interior territorial dos estados brasileiros, trazem consigo características não mais presentes nas grandes cidades. São municípios que ainda possuem aspectos da vida rural em suas funções e, até mesmo, na formação do desenho urbano (GATTI; ZANDONADE, 2017). Tal aspecto é observado nas cidades que integram a região do Oeste Paulista.

\footnotetext{
${ }^{5}$ TEODORO SAMPAIO. Decreto Municipal no 2.699, de 30 de abril de 2021. Dispõe sobre a adoção de medidas de transição destinadas ao enfrentamento da Pandemia de COVID-19 e dá providências correlatas. Disponível em: https://www.teodorosampaio.sp.gov.br/temp/24072021205208ar quivo_DecretoMunicipal_.pdf. Acesso em: 24 jul. 2021.

6 "Expressando sua multiplicidade de significados, os vazios urbanos abrangem desde a inexistência de construção, à não ocupação, à desocupação, à decadência, ao não uso e ao subaproveitamento dos espaços, sejam eles terrenos ou edificações consideradas como urbanos [...]" (BELTRAME, 2013, p. 115).
} 
Localizado no extremo oeste do Estado de São Paulo, e distante cerca de $653,8 \mathrm{~km}$ da capital do Estado, São Paulo, o município de Teodoro Sampaio ${ }^{7}$ (Figura 01), assim como os demais da região se desenvolveu a partir da implantação da Estrada de Ferro Alta Sorocabana pela FEPASA (Ferrovia Paulista S.A.), formando um trecho do Ramal de Dourados. Fundada em 07 de janeiro de 1952, por José Miguel de Castro Andrade e Odilon Ferreira, a cidade recebeu este nome em homenagem ao Engenheiro Theodoro Sampaio, responsável pelo primeiro levantamento geográfico do Pontal do Paranapanema em 1886 (PREFEITURA MUNICIPAL DE TEODORO SAMPAIO, 2019).

\footnotetext{
${ }^{7}$ Teodoro Sampaio possui uma estimativa de 23.273 habitantes, 2020, de acordo com dados do IBGE. Disponível em: https://www.ibge.gov.br/cidades-e-estados/sp/teodorosampaio.html. Acesso em: 14 de jul. 2021.
} 
Figura 01. Localização de Teodoro Sampaio no Estado de São Paulo e delimitação do perímetro urbano.

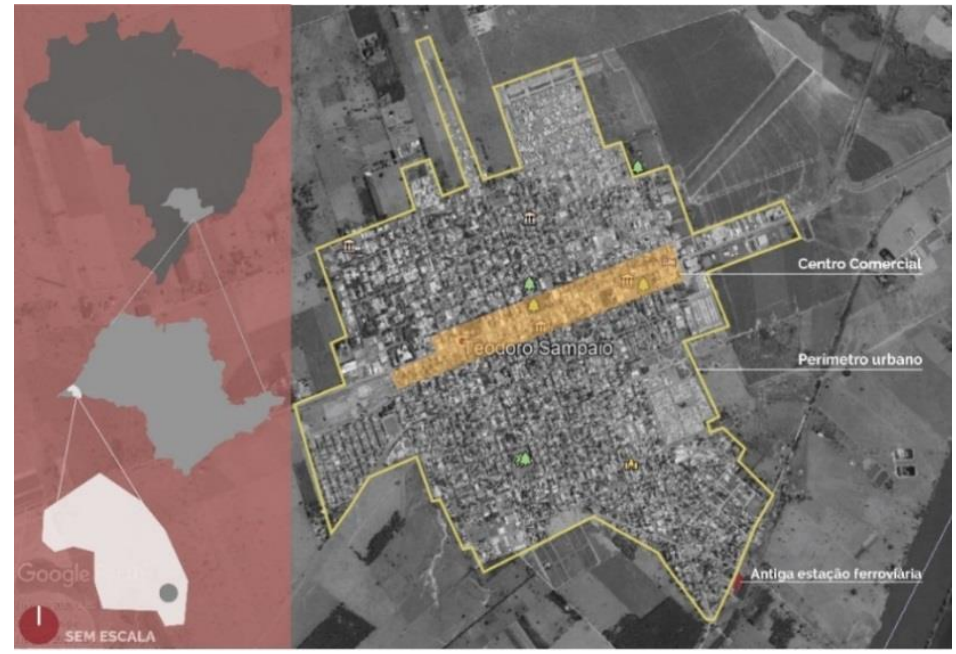

Fonte: Google Earth (2019), editado pelos autores (2020).

A implantação da Estrada de Ferro Alta Sorocabana e o trecho constituído pelo Ramal de Dourados refletiu positivamente no território, de modo que a circulação de pessoas e a visualização de potencialidades econômicas, apoiado no transporte de passageiros e de cargas, impulsionou a conquista do título de município de Teodoro Sampaio em 28 de fevereiro de 1964, a partir do decreto de lei no 8.092. Esta conquista, consequentemente, deu subsídios para a sua emancipação política administrativa em 21 de março de 1965 (SOUZA, 2002).

Com o início da década de 1970, o declínio do sistema ferroviário implantado já era uma condição existente e a queda da produção agrícola e madeireira foram outros fatores determinantes para a desativação do Ramal de Dourados em 1981. Entretanto, mesmo que a ferrovia tenha se apresentado nestas décadas economicamente inviável para a região do Oeste Paulista, no ano de 1988 houveram iniciativas de reativação do ramal por parte da área técnica da FEPASA. Tal fato só seria concretizado, caso a ferrovia atendessem recomendações específicas, condições estas que não ocorreram, levando a retirada dos trilhos no ano de 1999, e, atualmente, 2021, apenas restam algumas ruínas da antiga estação ferroviária de Teodoro Sampaio no bairro Jardim Esplanada (SOUZA, 2002).

A configuração urbana no município se deu baseado na área remanescente da linha férrea, que durante a ascensão da ferrovia foi um dos pontos nodais da economia e da circulação de pessoas na cidade de Teodoro Sampaio. No entanto, com a desativação do Ramal de Dourados os deslocamentos intra-urbanos mudaram, sendo focalizados no centro comercial, definido a partir da Avenida Cuiabá, já que a mesma se interliga com as rodovias intermunicipais e possui uma circulação maior de pessoas e veículos automotores (Figura 02). 
Figura 02. Avenida Cuiabá e ligação com as rodovias intermunicipais em Teodoro Sampaio.

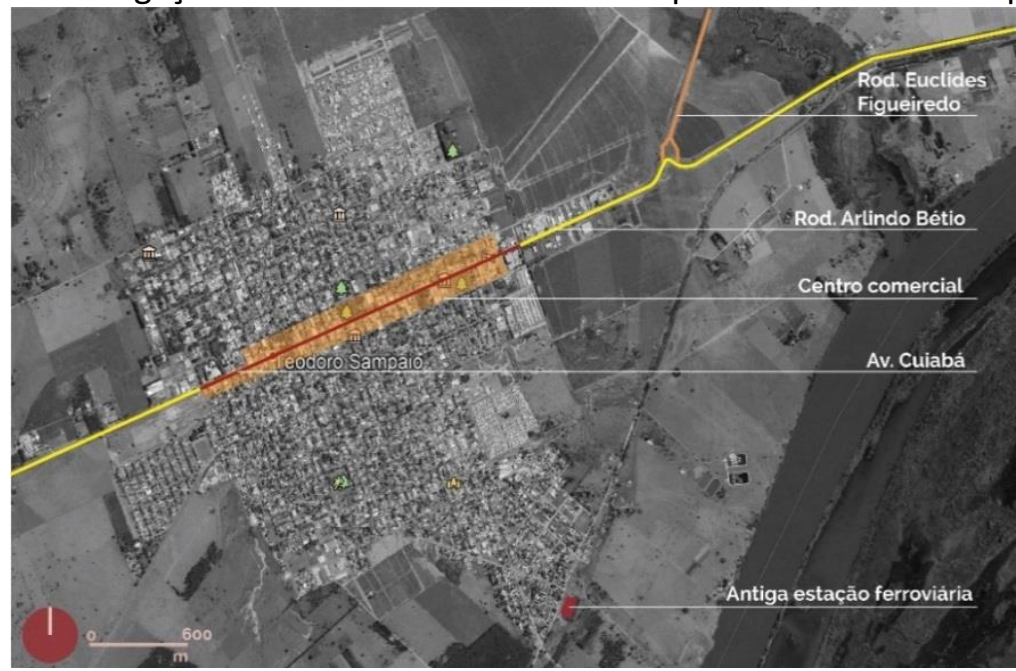

Fonte: Google Earth (2019), editado pelos autores (2020).

As produções do espaço urbano geram diferentes centralidades devido ao deslocamento do comércio, dos serviços públicos e do lazer, estas transformações acabam indo de acordo com as funções de cada lugar (CARLOS, 2007). Dessa forma, a cidade tende a privilegiar determinadas áreas, no sentido de abrir avenidas, impedir ou determinar usos específicos, o que incide diretamente na sociabilidade, na valorização ou desvalorização de bairros, acentuando desta maneira a desigualdade, conforme verificado no bairro Jardim Esplanada.

O bairro Jardim Esplanada, se constituiu em Teodoro Sampaio a partir das décadas de 1960 e 1970, sendo popularmente conhecido como "bairro da estação" e abrangia uma área bem maior do que atualmente, por conta da atividade da estação ferroviária e extensão do Ramal de Dourados (SOUZA, 2002).

Dentro da configuração urbana do município de Teodoro Sampaio, o bairro encontra-se em uma porção periférica em relação ao centro comercial, concentrando uma parcela considerável de moradores com menor renda e mulheres que, em sua maioria, são donas de casa e há poucas opções de atratividade em seus espaços públicos, o que reflete diretamente nas formas de apropriação das mulheres no espaço urbano.

Localizado na porção sudeste do município, a uma distância aproximada de $1,8 \mathrm{~km}$ do centro comercial (Figura 03), o Jardim Esplanada é formado predominantemente de residências térreas e com comércios de bairro pontuais, como: mercearias, padarias e até pequenas lojas. Devido à falta de demanda e as distâncias percorridas nas cidades serem pequenas, não há transporte público coletivo para o deslocamento dos moradores a outros bairros, com exceção do transporte escolar que é realizado regularmente e atende todas as escolas de ensino público. 
Figura 03. Localização do bairro Jardim Esplanada em relação ao centro comercial de Teodoro Sampaio.

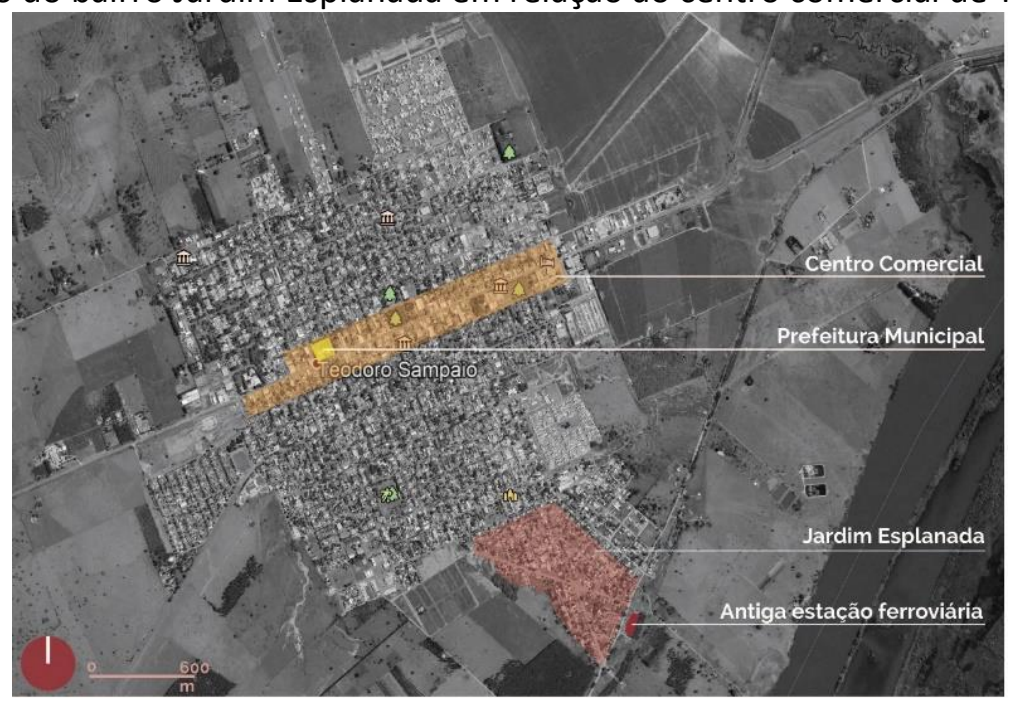

Fonte: Google Earth (2019), editado pelos autores (2020).

Os equipamentos públicos no perímetro do bairro estão orientados para as necessidades básicas. Há uma creche, um Posto de Saúde da Família (PSF), uma Piscina Municipal, a Câmara Municipal, uma quadra poliesportiva e uma academia ao ar livre destinada para idosos na Praça dos Ferroviários (Figura 04). Deste modo, nota-se que ele possui áreas destinadas ao uso coletivo, porém o que se observa no cotidiano é a ausência de respaldos a fim de que as mulheres utilizem tais espaços públicos de lazer com maior frequência.

A implantação de equipamentos de lazer deve possuir também uma dimensão de gênero: de um lado à necessidade de lazer para seus filhos e de lugares seguros para que crianças e adolescentes possam usufruir de educação, cultura e entretenimento; de outro a necessidade de lazer e descanso para as mulheres se identifica como prioritária a implantação de equipamentos de lazer em imóveis abandonados da cidade em especial na periferia (CYMBALISTA; CARDOSO; SANTORO, 2008, p. 14).

As atividades públicas de lazer promovidas pelo poder público em Teodoro Sampaio estão localizadas nas praças situadas no centro comercial da cidade, mais especificamente na Avenida Cuiabá. A falta de áreas de convívio público, lotes vazios e abandonados, ausência de calçada e a insuficiência de iluminação pública em determinados pontos do Jardim Esplanada, acaba agravando os fatores de insegurança das mulheres. 
Figura 04. Localização dos equipamentos públicos no bairro Jardim Esplanada.

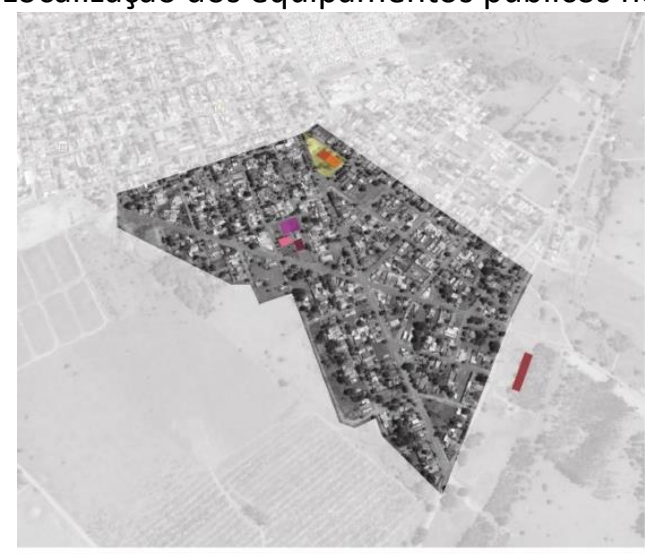

LEGENDA

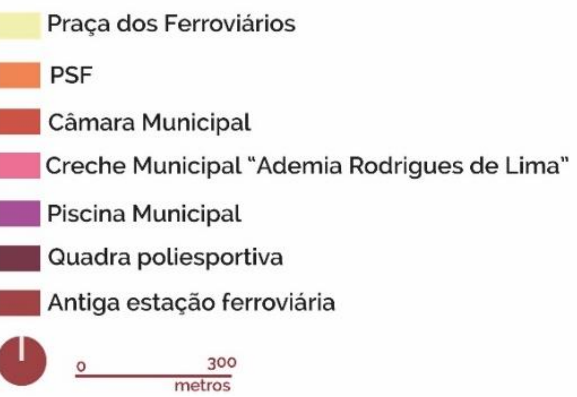

Fonte: Google Earth (2020), editado pelos autores (2020).

Segundo informação informal da Secretaria de Obras e Planejamento do Município de Teodoro Sampaio, em 2019, muitos proprietários de lotes adquiridos no período de loteamento do bairro, mudaram para outras cidades e outros já faleceram, o que ocasionou em muitas ocupações irregulares e abertura de processos de usucapião ${ }^{8}$. O Jardim Esplanada possui o menor índice de lotes registrados em cartório, e, estes são responsáveis por grande parte das áreas ociosas e de vulnerabilidade para as mulheres moradoras do bairro, além disso, construções abandonadas são encontradas com frequência. (Figura 05).

\footnotetext{
${ }^{8}$ Segundo o Art. 183 da Constituição Federal de 1988 “Aquele que possuir como sua área ou edificação urbana de até duzentos e cinquenta metros quadrados, por cinco anos, ininterruptamente e sem oposição, utilizando-a para sua moradia ou de sua família, adquirir-lhe-á o domínio, desde que não seja proprietário de outro imóvel urbano ou rural".
} 
Figura 05. Mapa figura-fundo do bairro Jardim Esplanada com destaque para alguns vazios urbanos.

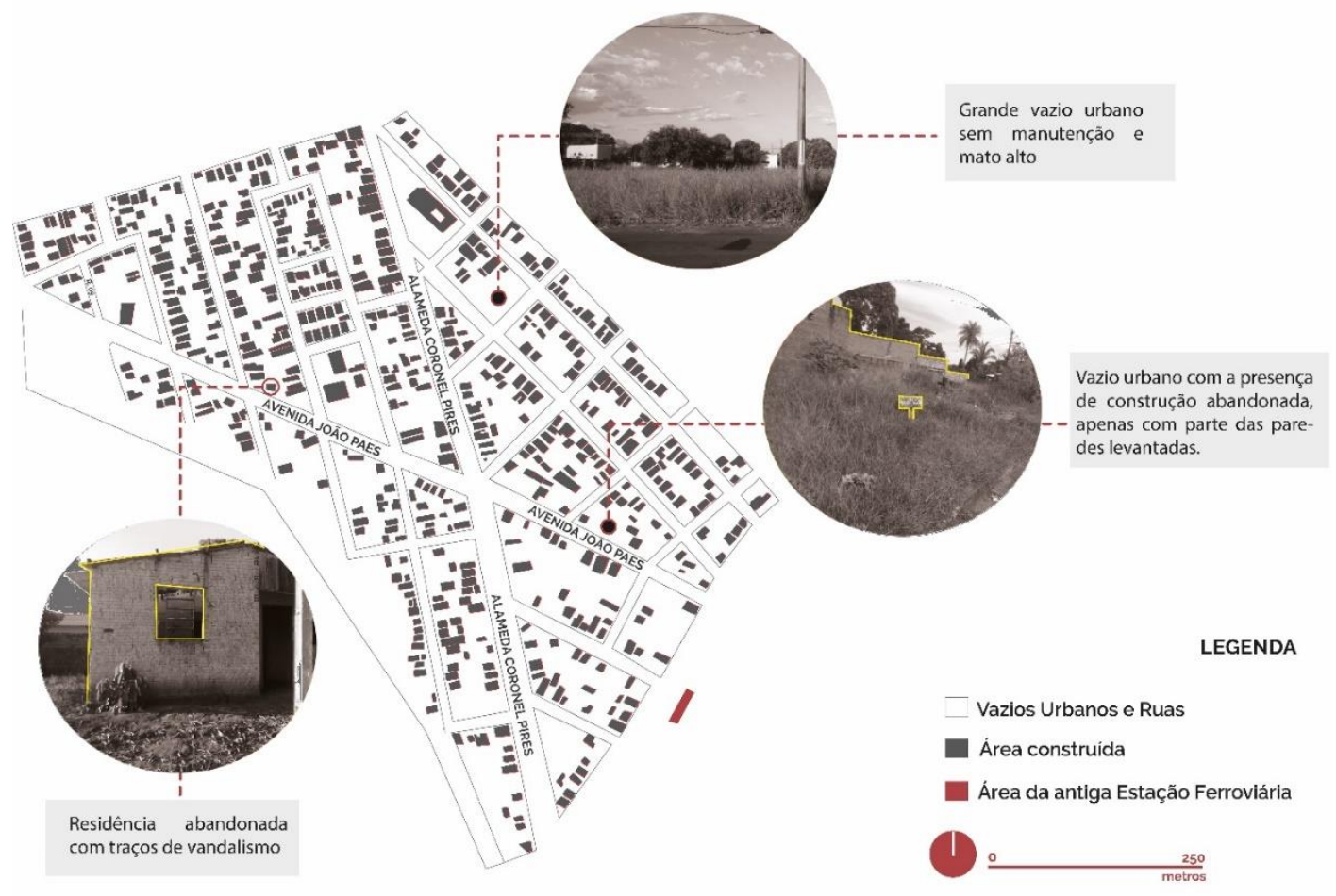

Fonte: Google Earth (2019), editado pelos autores (2020).

A ausência de controle público sobre as terras urbanas existentes no bairro Jardim Esplanada no cumprimento da sua função social ${ }^{9}$, em especial nos vazios urbanos, que são os principais indutores de insegurança nas mulheres, permite que os proprietários destes locais se mantenham isentos das responsabilidades sociais e urbanas. No município de Teodoro Sampaio, a vigilância sanitária é o único órgão público que fiscaliza as propriedades, e, em caso de denúncia, deve-se efetuar a limpeza dos lotes vazios, entretanto, no bairro Jardim Esplanada é observado que a maioria dos vazios urbanos não está com a manutenção realizada.

Ainda que, muitas vezes, sem pavimentação, as calçadas no bairro são os espaços de maior interação entre os moradores e a rua. Ainda assim, como algumas ruas ficaram muitos anos sem pavimentação, percebe-se que alguns proprietários acabaram invadindo a área destinada à calçada. Esta questão resultou em locais em que o tráfego de pedestres acontece na rua, fato que, prejudica a mobilidade das

\footnotetext{
9 Segundo o Art. 182 §2ㅇ da Constituição Federal de 1988 "A propriedade urbana cumpre sua função social quando atende às exigências fundamentais de ordenação da cidade expressas no plano diretor".
}

mulheres com crianças no momento em que vão à creche do bairro pela Avenida João Paes, por exemplo (Figura 06). 
Figura 06. Obstáculos e redução da calçada devido a apropriação inadequada no bairro Jardim Esplanada.

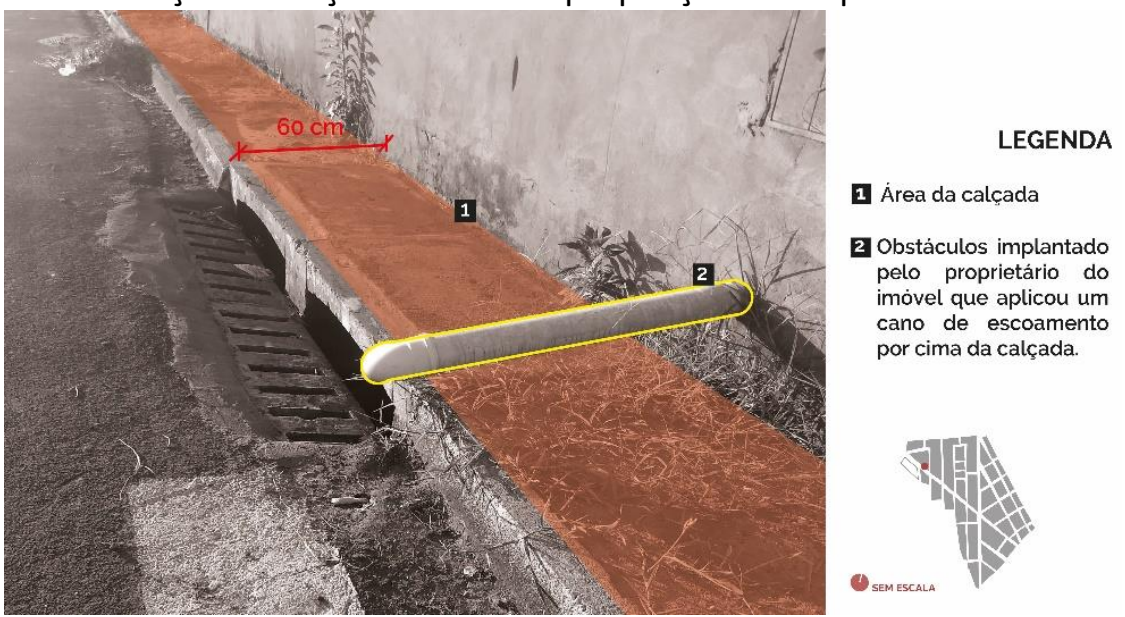

Fonte: Arquivo dos autores (2020).

Durante os levantamentos foi possível notar que alguns postes estão obstruídos por resíduos de pássaros, foram utilizados como ninhos, o que prejudica a iluminação pública e devido à falta de manutenção pode resultar em danos à parte elétrica (Figura 07).

Figura 07. Obstrução da iluminação pública no bairro Jardim Esplanada.

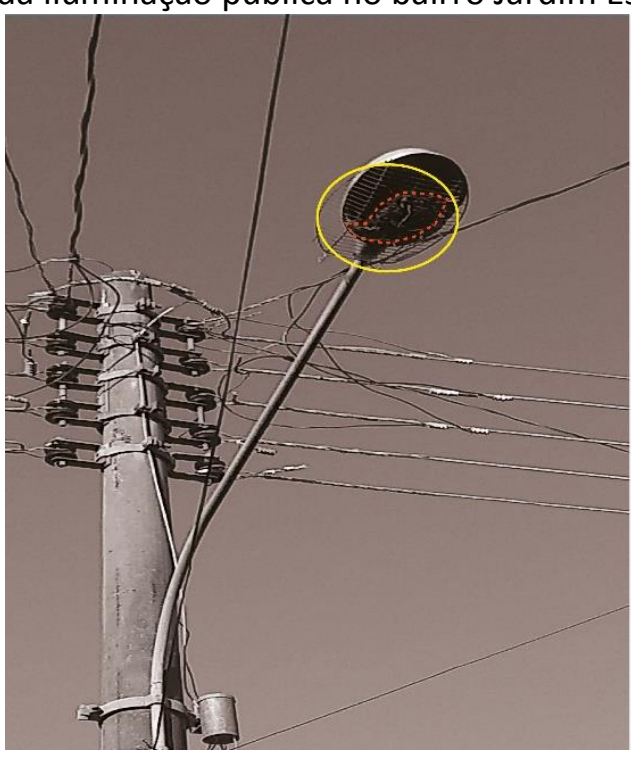

LEGENDA

Obstrução

Grade de proteção deslocada

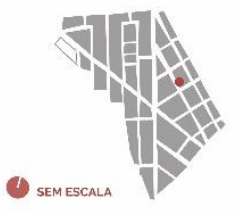

Fonte: Arquivo dos autores (2020).

A partir da abordagem das características do bairro Jardim Esplanada e considerando a baixa qualidade da infraestrutura urbana, é válido relacionar com as leis existentes acerca do desenvolvimento urbano do município de Teodoro Sampaio, a fim de compreender as dinâmicas das políticas públicas aplicadas com relação às vivências urbanas, tal como sua influência na apropriação da mulher à cidade.

Ao tratarmos sobre políticas públicas no desenvolvimento de diretrizes urbanas, considera-se um processo de ação governamental, visando coordenar os meios à disposição do Estado e as atividades privadas, para a realização de objetivos e soluções socialmente relevantes e previamente determinadas ( $\mathrm{BUCCl}, 2002$ ). À vista disso, as prefeituras possuem $\mathrm{o}$ papel de propor e regulamentar as ações envolvendo as diversas camadas da cidade, e entender as necessidades imediatas da população. 
Como possui mais de vinte mil habitantes, Teodoro Sampaio estabeleceu na lei municipal no 21 de 10 de outubro de 2006, sob aprovação do prefeito José Ademir Infante Gutierrez, o Plano Diretor instituiu as diretrizes de orientação ao desenvolvimento municipal, com características de ocupação e leis complementares para o seu devido ordenamento. Entretanto, de fato, pouco foi executado.

Das leis estabelecidas como complementares ao Plano Diretor, a Lei de Uso e Ocupação do Solo não chegou a ser elaborada (até o final deste estudo), assim, não há parâmetros estabelecidos na prática. A Lei de Parcelamento do Solo, no 28 de 16 de maio de 2007, estabelece definições e algumas diretrizes a serem seguidas nos processos de parcelamento e construção.

Mesmo com a existência da Lei de Parcelamento do Solo e diretrizes expostas no Código de $\mathrm{Obras}^{10}$, ainda há um número significativo de construções sem alvará de construção, caracterizando a ocupação como irregular, de modo que, na maioria das vezes, estas obras ocorrem sem o acompanhamento de um profissional, o que consequentemente provoca problemas futuros, tanto estruturais, quanto legais, quando se trata de um lote em processo de usucapião.

Diante das legislações urbanísticas que Teodoro Sampaio apresenta, e observando a necessidade de melhorias, em outubro de 2019, o prefeito Ailton Cesar Herling determinou um grupo para a revisão do Plano Diretor de $2006^{11}$. O grupo foi estabelecido com a intenção de sua revisão ser uma colaboração participativa com a população, a fim de implementar o Plano de Mobilidade Urbana Municipal e, até o momento da conclusão deste estudo, 2021, o processo se encontra na fase de apresentação do diagnóstico para a população e $o$ arquivo com os levantamentos e mapas está no site da prefeitura. Porém, segundo seu cronograma, a instrumentação do Plano Diretor e publicação da

\footnotetext{
${ }^{10}$ Teodoro Sampaio. Lei municipal complementar no 27 de 25 de abril de 2007. "Institui o Código de Obras e Edificações do Município de Teodoro Sampaio - SP, e dá Outras Providências".

11 TEODORO SAMPAIO. Decreto municipal no 2.534 de 30 de outubro de 2019. Dispõe sobre: "Institui Grupo de Trabalho destinado ao acompanhamento da revisão da Lei Complementar no 21, de 10 de outubro de 2006, que dispõe sobre o Plano Diretor de Teodoro Sampaio, bem como a elaboração e a implementação do Plano Municipal de Mobilidade Urbana".
}

lei municipal deveriam ocorrer até dezembro de 2020, o que não ocorreu.

Embora, mesmo sem a efetiva implantação de medidas no Plano Diretor, que atenda às necessidades diretas das mulheres em Teodoro Sampaio, no ano de 2004, pela iniciativa da vereadora Sueli Di Gesu e sob o mandato do prefeito Paulo Alves Pires, determinou-se juridicamente a criação do Conselho Municipal dos Direitos da Mulher ${ }^{12}$, vinculado à Secretaria de Assistência Social. O Conselho Municipal deveria formular diretrizes, programas e políticas públicas relacionadas com a promoção da melhoria das condições de vida das mulheres e a eliminação de todas as formas de discriminação e violência contra as mesmas, buscando assegurarIhes plena participação e igualdade nos planos político, econômico, social, cultural e jurídico. Todavia, tal lei só existe teoricamente, e, não foi colocada em prática.

É necessário, portanto, ampliar as concepções do planejamento urbano municipal para que o mesmo reconheça o território como espaço também pertencente à mulher, como cidadã, ratificando o direito de usufruir do espaço público e garantir subsídios como estabelece o Estatuto da Cidade. Diante disso, pode-se considerar que o município de Teodoro Sampaio possui leis e aparato jurídico para a orientação do desenvolvimento do ambiente urbano, porém cabe ao poder público colocá-los em prática com o objetivo de minimizar as condições de vulnerabilidade das mulheres na cidade, como no bairro Jardim Esplanada.

\section{DISCUSSÃO}

\section{1. $O$ espaço (não) vivenciado pela mulher: Os pontos de vulnerabilidade levantados em visitas in loco no bairro Jardim Esplanada}

As discussões acerca das apropriações urbanas das mulheres no Jardim Esplanada em Teodoro Sampaio estão apresentadas de acordo com as visitas realizadas in loco no bairro de janeiro a março de 2020 e intercaladas com observações realizadas em maio de 2021, para entendimento da importância da aplicação de políticas públicas no desenvolvimento da cidade, principalmente em áreas periféricas. Dentre esses espaços, vale destacar a existência dos

\footnotetext{
12 TEODORO SAMPAIO. Lei Municipal no 1.374 de 15 de junho de 2004. Dispõe sobre: Cria o Conselho Municipal dos Direitos da Mulher e dá outras providências. 2004.
} 
equipamentos de uso público e coletivo no bairro e suas formas de apropriação, conforme já destacado inicialmente.

Considerando os potenciais problemas de circulação e vulnerabilidade feminina no bairro Jardim Esplanada e, visto que as visitas ocorreram de modo individual, no total 8 , o percurso foi realizado de bicicleta, em sua maioria nos períodos da tarde, devido a iluminação pública possuir insuficiências e a movimentação de pessoas ser baixa em alguns pontos do bairro, o que aumenta as sensações de insegurança.

A primeira visita de campo realizada no perímetro do Jardim Esplanada, foi no dia $\mathbf{2 7}$ de janeiro de 2020, por volta das 17:30h. O acesso ao bairro, se deu a partir da Alameda Coronel Pires, onde se obteve o primeiro contato com a área de estudo, por meio da Praça dos Ferroviários e Câmara Municipal, em direção à antiga estação ferroviária, pois neste trecho há uma certa movimentação devido aos edifícios públicos. A principal percepção foi quanto à concentração de crianças e adolescentes de diferentes faixas etárias na praça, mais especificamente na pista de skate, inaugurada em janeiro de $2020^{13}$.

A movimentação predominante na praça era de homens de meia-idade, sendo observadas apenas duas mulheres de meia-idade conversando em um banco paralelo à lateral da praça, em frente a uma das casas (Figura 08). Seguindo a visita pela Rua Antônio Ferreira de Paula, na qual pode-se notar um número significativo de vazios urbanos e subutilizados, no total de 11, variando entre áreas de hortas e construções completamente abandonadas, resultando na formação de áreas de insegurança nos períodos noturnos.

\footnotetext{
${ }^{13}$ A construção foi aprovada conforme o convênio no 37/2018, firmado com a Secretaria de Estado de Esporte, Lazer e Juventude, sendo finalizada em janeiro de 2020 (TEODORO SAMPAIO, 2019).
} 
Figura 08. Mulheres fazendo uso da calçada em frente à Praça dos Ferroviários na Al. Coronel Pires em 27 de janeiro de 2020 no bairro Jardim Esplanada.

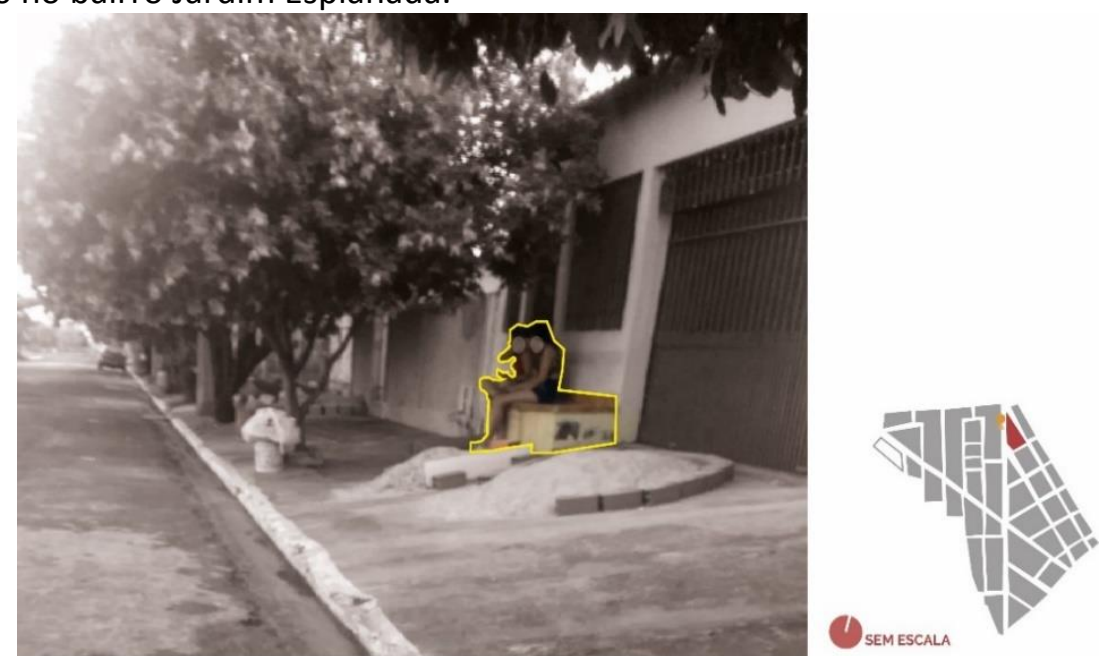

Fonte: Arquivo dos autores (2020).

No cruzamento da Alameda Coronel Pires com a Av. João Paes, foi possível perceber que a calçada e a rua são locais de ampla circulação e permanência de mulheres e crianças, seja ela apenas para conversar ou apenas para ficar olhando as crianças que brincam nas ruas (Figura 09).

Figura 09. Mulher fazendo uso da calçada para observar as crianças no Jardim Esplanada em 27 de janeiro de 2020.
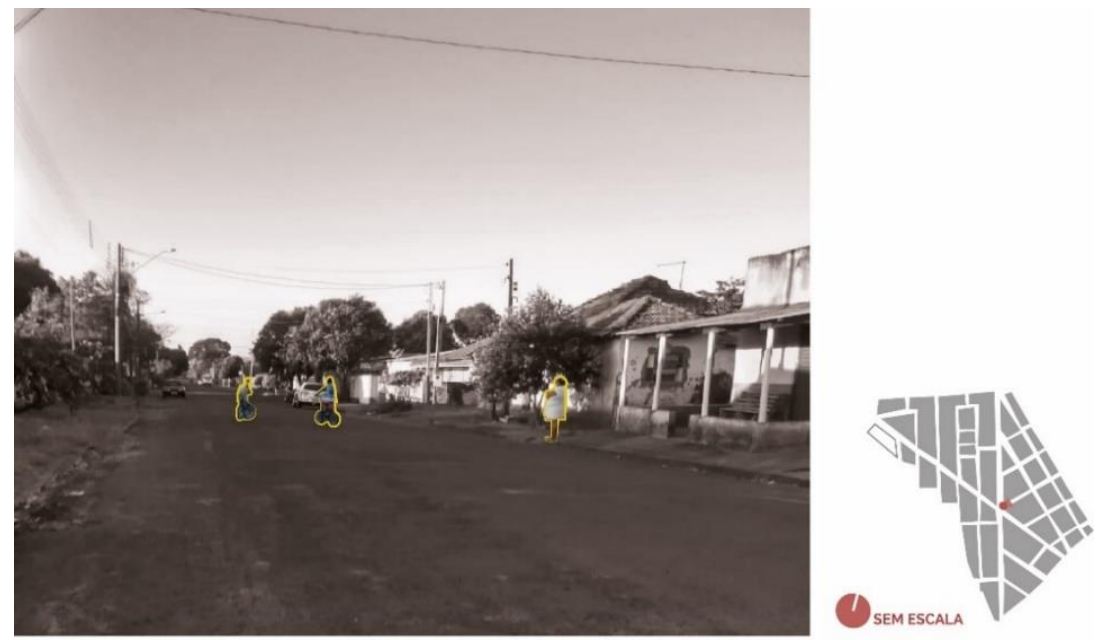

Fonte: Arquivo dos autores (2020).

O entorno imediato da Praça dos Ferroviários, assim como outros pontos com equipamentos públicos no bairro possuem uma circulação de pessoas mais considerável, porém, a presença das mulheres acontece efetivamente na rua ou nas calçadas, em sua maioria, acompanhadas de outra mulher ou crianças, provavelmente, por motivo de segurança e proximidade ao espaço doméstico (Figura 10). 
Figura 10. Relação dos principais pontos de apropriação de mulheres observados entre janeiro e março de 2020 no bairro Jardim Esplanada.

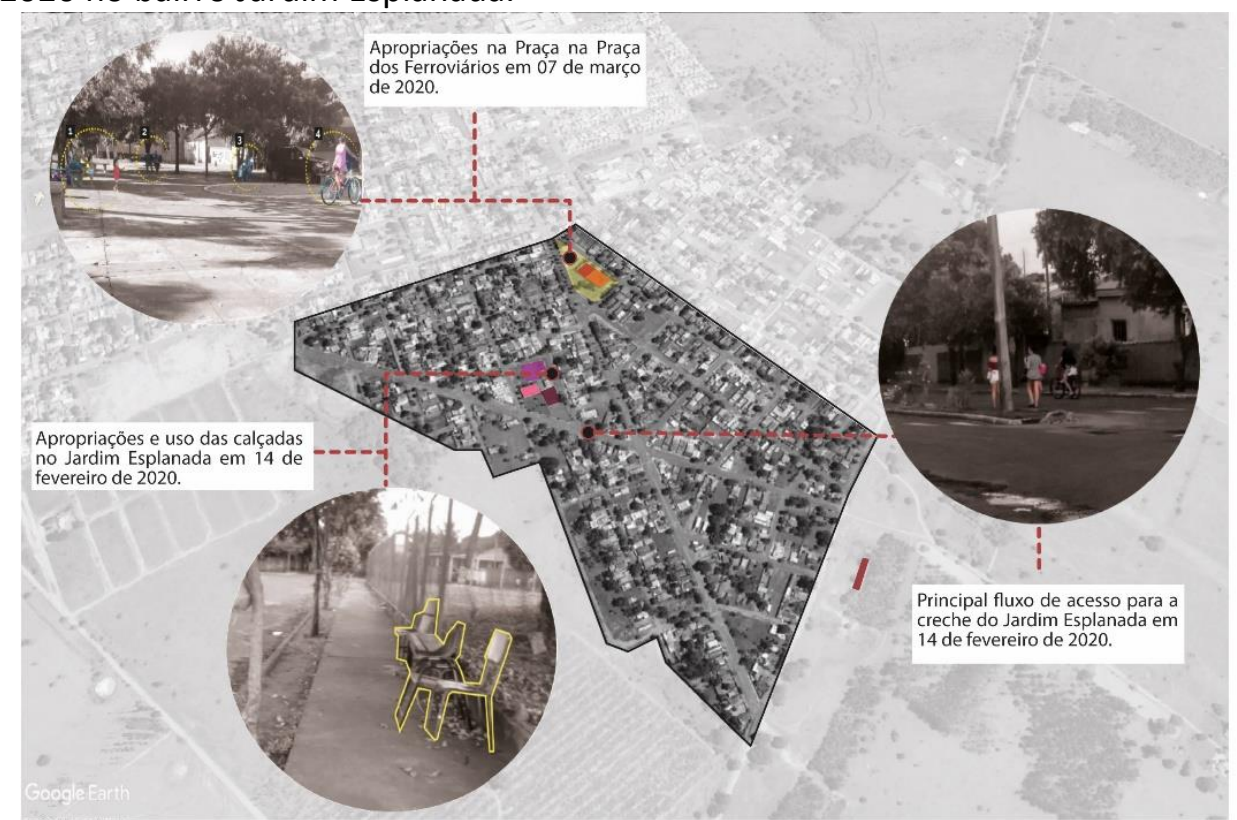

LEGENDA

Fonte: Google Earth (2020), elaborado pelos autores (2021).

No decorrer das visitas ao bairro, também pode-se perceber que mais próximo às ruínas da antiga Estação Ferroviária, maior é o número de vazios urbanos, onde na Avenida João Paes até o cruzamento com a Rua Lázaro Ferreira de Souza, igualmente, foi perceptível um aumento de construções abandonadas e lotes sem uso e com necessidade de manutenção, por isso, foi estabelecido um recorte de um ponto bastante específico para representação (Figura 11).

Figura 11. Indicação da área de recorte para análise no bairro Jardim Esplanada.

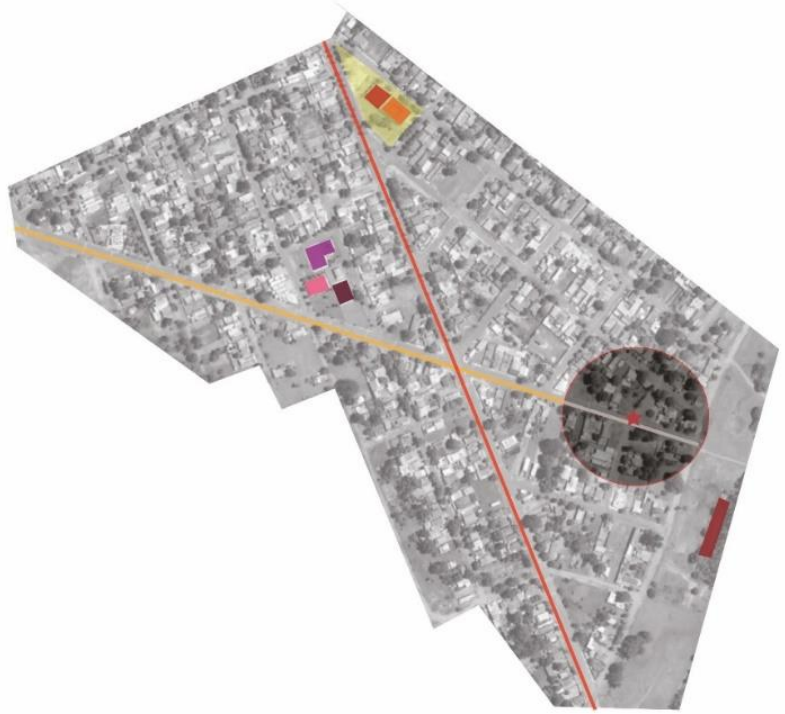

Fonte: Google Earth (2020), elaborado pelos autores (2021).

LEGENDA

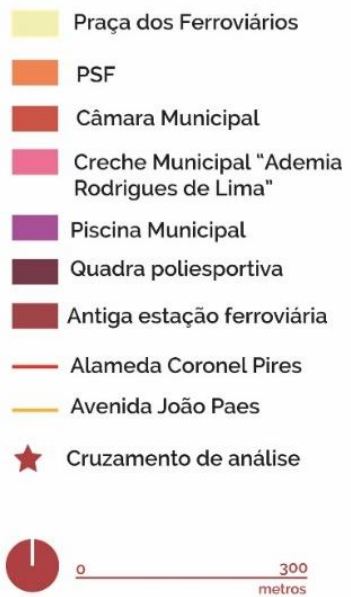

Na visita de 14 de fevereiro de 2020, por volta das 16:00h, no cruzamento e nas ruas paralelas não havia pessoas transitando e nem ocupando as calçadas, o que deixava o local com uma sensação de mais vazio (Figura 12). 
Figura 12. Áreas ociosas e de insegurança no bairro Jardim Esplanada em 14 de fevereiro de 2020.

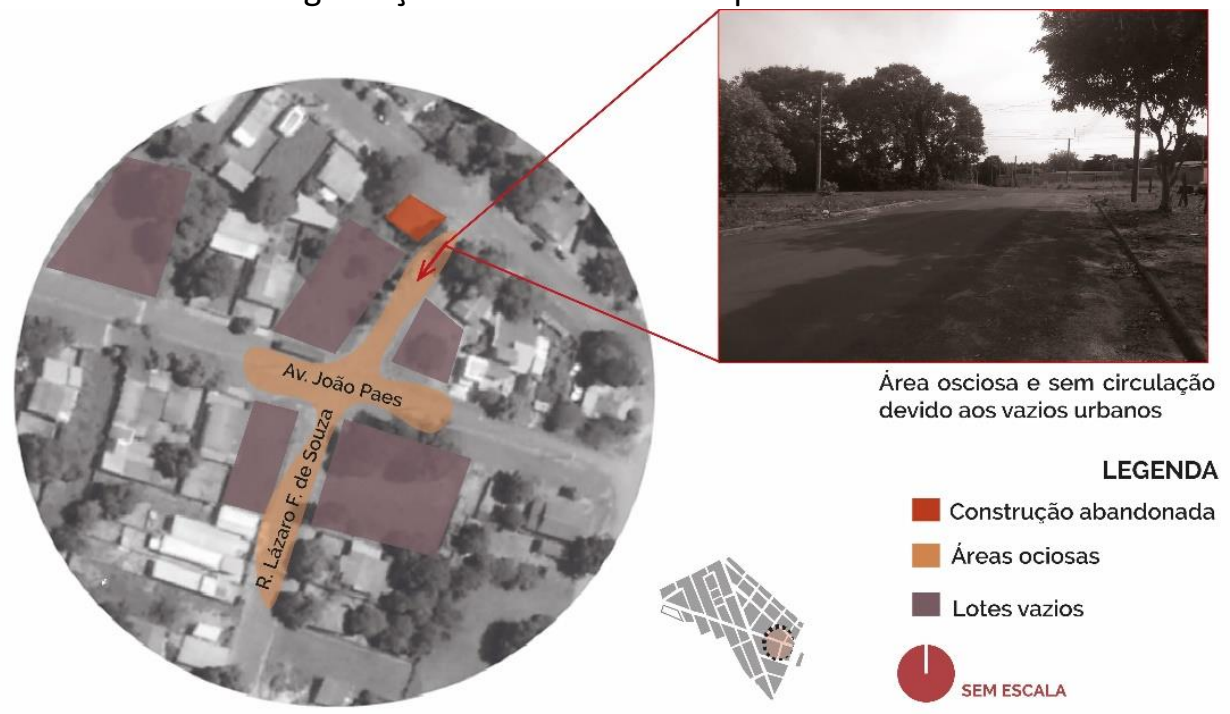

Fonte: Google Earth (2019), editado pelos autores (2020).

A falta de circulação de pessoas neste trecho do bairro se tornou perceptível não só para quem reside no entorno, desencadeando outras formas de ocupação momentâneas. Durante as visitas realizadas em maio de 2021, logo ao chegar no cruzamento, notou-se que um trecho da Rua Lázaro Ferreira de Souza estava em uso por uma autoescola como local de treinamento das aulas práticas de condutores (Figura 13).

Figura 13. Ocupação da autoescola na Rua Lázaro Ferreira de Souza em 10 de maio de 2021 no bairro Jardim Esplanada.

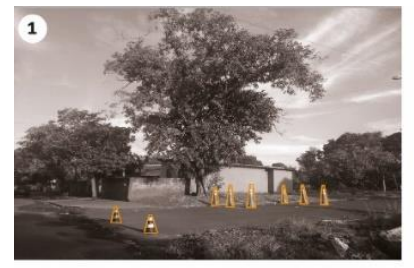

Sinalização da autoescola na R. Lázaro F. de Souza

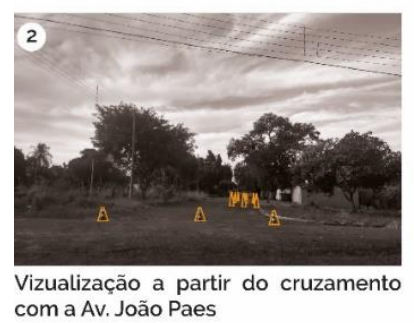

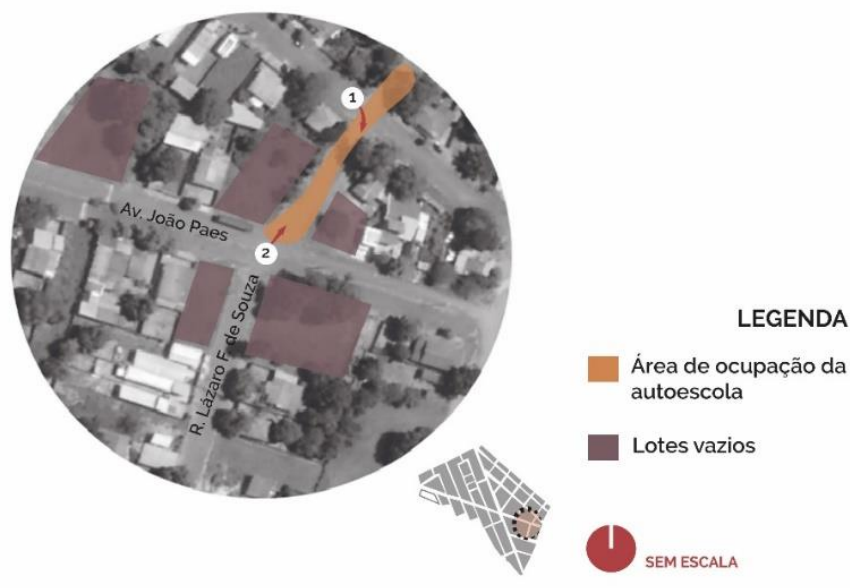

Fonte: Google Earth (2020), elaborado pelos autores (2021).

De acordo com o art. 158 do Código de Trânsito Brasileiro ${ }^{14}$, o local de aprendizagem é aprovado previamente pelo Órgão Executivo de

\footnotetext{
${ }^{14}$ BRASIL. Lei 9.503 de 23 de setembro de 1997. Institui o Código de Trânsito Brasileiro. Brasília, 1997. Disponível em: http://www.planalto.gov.br/ccivil_03/leis/19503compilado.htm. Acesso em: 18 jul. 2021.
}

Trânsito, ou seja, se o espaço está sendo utilizado para tal fim, o poder público deve estar ciente. Conforme demonstrado nas imagens anteriores de 2020, o espaço possuía vazios urbanos, pouca iluminação e construções abandonadas, porém, a partir do uso da autoescola a edificação em 
estado de abandono foi demolida, mas não houve a completa limpeza do lote (Figura 14).

Figura 14. Construção abandonada demolida na Rua Lázaro Ferreira de Souza no bairro Jardim Esplanada.
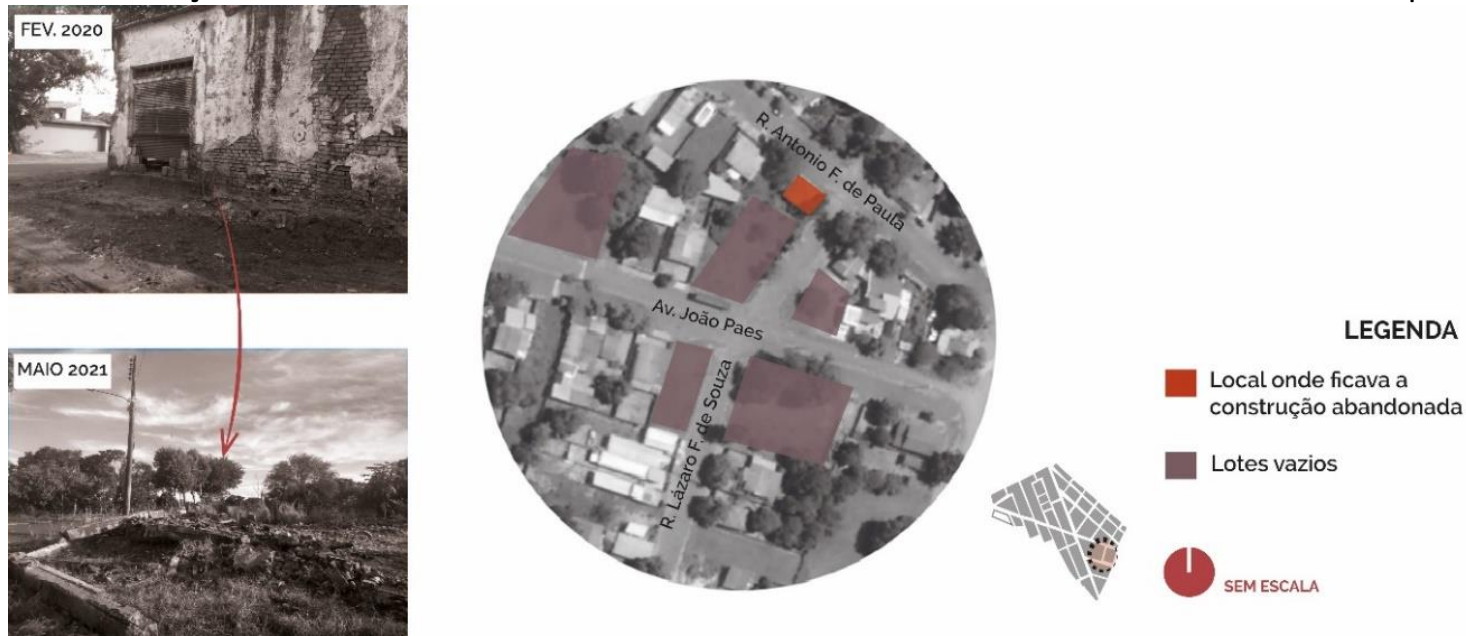

Fonte: Google Earth (2020), elaborado pelos autores (2021).

Ao traçar um paralelo entre as formas de ocupação do trecho do recorte nos períodos de análise, é notável que a falta de pessoas transitando em pontos do bairro Jardim Esplanada continua, assim como nas análises do ano anterior. Todavia, a circulação de veículos na Rua Lázaro Ferreira de Souza aumentou atualmente, 2021, por conta do treinamento de condutores de veículos, o que pode contribuir nas sensações de segurança, durante boa parte do dia e da noite.

Mesmo assim, não houveram avanços no aspecto de inserção de políticas públicas para incentivo de maior uso daquela área, com melhorias na manutenção da iluminação pública e limpeza dos vazios urbanos, ao invés, da restrição de uso para uma única finalidade, pois nos períodos em que não há aulas, a ociosidade e insegurança voltam a se tornar presentes para muitas mulheres. Apesar do novo uso da rua, a mobilidade para elas acaba se restringindo próximo aos equipamentos públicos ou em frente de suas casas, em razão da proximidade, logo que o espaço privado é visto como seguro, embora ocupar o espaço público seja um exercício de direito à cidade.

Todos os caminhos percorridos neste trabalho foram importantes para compreender melhor sobre como é o comportamento da mulher no espaço urbano e como certos elementos, por mais corriqueiros que pareçam, influenciam diretamente na vivência coletiva e podem passar despercebidos pelo poder público na formulação de políticas públicas.

Esta pesquisa no bairro Jardim Esplanada em Teodoro Sampaio - SP, verificou a existência de equipamentos urbanos, e, certo investimento nos edifícios públicos e de serviço aos moradores e ao município. Entretanto, também ficou evidente a ausência de infraestrutura urbana e um grande número de vazios urbanos e abandonados, responsáveis por limitar a vivência da mulher no espaço urbano.

As mulheres vistas utilizando a Praça dos Ferroviários e os demais espaços públicos do bairro, em sua maioria, estavam acompanhadas dos filhos, sobrinhos ou netos, sentadas e apenas observando as crianças, não possuindo uma relação muito próxima de apropriação. Desta forma, é importante destacar a necessidade de locais de uso coletivo favoráveis a população, visto que, a praça não dispõe de investimentos em atividades culturais ou atrativas, que em conjunto com o número significativo de vazios urbanos no Jardim Esplanada, como no cruzamento entre a Av. João Paes e Rua Lázaro Ferreira de Souza, resulta em áreas de vulnerabilidade nos períodos noturnos.

Deste modo, vale ressaltar, a importância de o planejamento urbano em possibilitar a apropriação das mulheres nos ambientes públicos, marcando a sua presença e contribuindo para a sua inclusão, por meio de ações sociais, não só dos profissionais responsáveis pelo planejamento urbano, mas de 
todos os cidadãos, de onde devem partir as discussões sobre o tema e que, em consequência, possam proporcionar conhecimento sobre a cidade e suas apropriações.

$\mathrm{O}$ direito à cidade e a perspectiva de gênero, no que diz respeito à integração de todas as formas de apropriação, é uma discussão realizada a muitos anos, onde a criação de espaços igualitários é um dos grandes desafios da Nova Agenda Urbana (Habitat III), Agenda 2030 ONU e os 17 Objetivos de Desenvolvimento Sustentável (ODS), por exemplo. De modo que tornar aparente a diferença nas formas de uso da cidade, é um dos primeiros passos a serem tomados para a construção de um cenário mais participativo para as mulheres, abrindo possibilidades delas se expressarem a partir da sua própria experiência urbana.

$\mathrm{O}$ acesso aos meios governamentais e a participação significativa das mulheres são cruciais para o desenvolvimento de uma urbanização mais inclusiva. Participar nos assuntos da vida pública é um direito humano e compreende o direito de votar em todas as eleições e em todos os referendos públicos, sendo elegíveis para todos os organismos publicamente eleitos (ONUBR, 2016).

Tendo em vista, que desde outubro de 2019, o município de Teodoro Sampaio encontrase em processo de revisão do Plano Diretor, e considerando a existência da lei 1.374/2004 relacionada à criação do Conselho de Direitos das Mulheres, propriamente, se faz necessária a participação da figura feminina no desenvolvimento urbano da cidade. Sua presença na política, nas decisões locais, associações de moradores e entre as equipes de formação, é fundamental para que suas vozes sejam ouvidas e suas necessidades representadas, resultando na formulação de um urbanismo mais igualitário sob a ótica de gênero.

\section{REFERÊNCIAS}

BELTRAME, G. Vazios urbanos: notas sobre a escassez social do imóvel urbano. Intersecções, Rio de Janeiro, v. 15, n. 1, p. 113-138, 2013.

BRASIL. Lei 10.257 de 10 de julho de 2001. Dispõe sobre o Estatuto da cidade. Brasília, 2001. Disponível em: http://www.planalto.gov.br/ccivil_03/LEIS/LEIS_2 001/L10257.htm. Acesso em: 18 jul. 2021.
$\mathrm{BUCCl}, \mathrm{M}$. P. D. Direito administrativo e políticas públicas. São Paulo: Saraiva, 2002.

CARLOS, A. F. A. 0 espaço urbano: novos escritos sobre a cidade. São Paulo: FFLCH, 2007.

CYMBALISTA, R.; CARDOSO, P. M.; SANTORO, P. F. O Plano Diretor Participativo e o direito das mulheres à cidade. São Paulo: Instituto Pólis. 2008.

FREITAS, M. R. P.; NEGRÃO, G. N. Vazios Urbanos: estudo de caso no município de Guarapuava - PR. Geographia Opportuno Tempore, Londrina, v. 1, (número especial), p. 480-493, 2014.

GALLETI, C. C. H. Direito a cidade e as experiências das mulheres no espaço urbano. In: Encontro Anual da ANPOCS (Associação Nacional de Pós-Graduação e Pesquisa em Ciências Sociais) GT34 - Urbanidades possíveis nos múltiplos usos da rua, 41., 2017, Caxambu, Anais Eletrônicos [...]. Caxambu, 2017. Disponível em: https://anpocs.com/index.php/encontros/papers /41-encontro-anual-da-anpocs/gt-30/gt34-8.

Acesso em: 18 jul. 2021.

GALEOTTI, A. E. Cidadania e diferença de gênero. O problema da dupla lealdade. In: BONACCHI, G.; GROPPI, A (org.). $O$ dilema da cidadania: Direitos e deveres das mulheres. São Paulo: Universidade Estadual Paulista, 1995, 235 p.

GATTI, S.; ZANDONADE, P. Espaços públicos: leitura urbana e morfologia de projeto [dos pequenos territórios às cidades médias]. Coordenação do Programa Soluções para Cidades. São Paulo: ABCP, 2017.

GONZAGA, T. O. A cidade e a arquitetura também mulher: conceituando a metodologia de planejamento urbano e dos projetos arquitetônicos do ponto de vista de gênero. 2004. 338f. Tese (Doutorado em Estruturas Ambientais Urbanas) - Faculdade de Arquitetura e Urbanismo de São Paulo, Universidade de São Paulo, São Paulo, 2004.

LEFEBVRE, H. O direito à cidade. São Paulo: Centauro, 2011.

LYNCH, K. A imagem da cidade. São Paulo: Martins Fontes, 1997. 
MARICATO, E. Para entender a crise urbana. São Paulo: Expressão Popular, 2015.

MONTANER, J. M.; MUXÍ, Z. Arquitetura e Política: ensaios para mundos alternativos. São Paulo: Gustavo Gili, 2014.

MORAES, L. R. Meio Cheio, Meio Vazio: uma análise dos vazios urbanos de Brasília. 2018. 211f. Dissertação (Mestrado em Projeto e Planejamento) - Programa de Pós-Graduação da Universidade de Brasília, Brasília, DF, 2018.

ORGANIZAÇÃO DAS NAÇÕES UNIDAS BRASIL (ONUBR). Glossário de termos do Objetivo de Desenvolvimento Sustentável 5: Alcançar a igualdade de gênero e empoderar todas as mulheres e meninas. Brasília: ONU, 2016. Disponível em:

http://www.onumulheres.org.br/wpcontent/uploads/2017/05/Glossario-ODS-5.pdf. Acesso em: 27 jul. 2021.

PECCINI, I. R. Pensamento feminista no planejamento urbano: pensar no território pela perspectiva de gênero - prática e epistemologia. Pixo, Pelotas, v. 3, n. 10, p. 56-73, 2019. Disponível em: https://periodicos.ufpel.edu.br/ojs2/index.php/pi xo/article/view/16864. Acesso em: 18 jul. 2021.

SANTORO, P. F. Gênero e planejamento territorial: uma aproximação. In: ENCONTRO NACIONAL DE ESTUDOS POPULACIONAIS, 16., 2008, Caxambu. Anais Eletrônicos [...]. Caxambu: ABEP, 2008. Disponível em: http://www.abep.org.br/ abeporgb/publicacoes/ index.php/anais/article/view/3378. Acesso em: 27 jul. 2021.

SANTORO, P. F.; COBRA, P. L.; BONDUKI, N. Cidades que crescem horizontalmente: 0 ordenamento territorial justo da mudança de uso rural para urbano. Cadernos Metrópole, São Paulo, v. 12, n. 24, p. 417-440, 2000.

SOUZA, J. M. Memorial Theodoro Sampaio: sua gente, sua história, sua geografia. Teodoro Sampaio: Gráfica Gonçalves, 2002.

TEODORO SAMPAIO. Prefeitura de Teodoro Sampaio, 2018. Página Inicial/ Imprensa/ Notícias/ Execução de Obras remanescentes de infraestrutura urbana. Disponível em:
https://www.teodorosampaio.sp.gov.br/?pag=T1 RVPU9EZz1PV0k9T1RrPU9UUT1OMIE9T0dNPU9X ST1PR1U9T0dNPU9HWT1PV009T1dZPQ==\&id=18 67. Acesso em: 19 jul. 2021.

PREFEITURA MUNICIPAL DE TEODORO SAMPAIO Teodoro Sampaio, 2019. Disponível em: https://www.teodorosampaio.sp.gov.br/?pag=T1 RjPU9EZz1PVFU9T0dVPU9HST1PVEE9TOdFPU9HR T0=\&idmenu=214. Acesso em: 19 jul. 2021. 